\title{
Problemy adaptacji mlodego nauczyciela do zawodu w polskiej teorii i praktyce pedagogicznej okresu międzywojennego
}

Polska pedeutologia okresu międzywojennego osiągnęła znaczne rezultaty będące wynikiem dociekań naukowych i uogólnień teoretycznych, jak i przydatnych w kształceniu nauczycieli doświadczeń praktycznych.

Kwestie te zostały w polskiej literaturze pedeutologicznej i historyczno-pedagogicznej obficie opisane. Warto tu wspomnieć m.in. prace Henryka Rowida, Stanisława Karpowicza, Anieli Szycówny, Władysława Spasowskiego, Jana Wladysława Dawida, Antoniego Bolesława Dobrowolskiego, Wladysława Radwana, Józefa Ciembrowicza, Józefa Mirskiego, Wandy Dzierzbickiej, Albina Jakiela, Izy Moszczeńskiej i wielu innych".

Ostatnio z korzystnym rezultatem do refleksji tych powróciła Barbara Żechowska, która w swoim studium pt.: Narodziny polskiej pedeutologii $i$ jej glówne linie rozwojowe, zamieszczonym w pracy zbiorowej: Rozwój pedagogiki w II Rzeczypospolitej. Problemy kontrowersyjne $(1918-1939)^{2}$, przygotowanej pod redakcja W. Bobrowskiej-Nowak, dokonała ich wnikliwego podsumowania.

Wydaje się, że podejmując próbę retrospekcji i wyeksponowania z poglądów polskich pedeutologów okresu międzywojennego ich stanowiska wobec problemu adaptacji młodego nauczyciela do zawodu, można zwrócić uwage m.in. na przynajmniej dwie podstawowe kwestie:

- po pierwsze - na przygotowanie nauczyciela do zawodu, a więc jego kształcenie i formowanie jego osobowości w określonym zakładzie kształcenia nauczycieli i panującą w nim atmosfere,

- po drugie - na pierwsze kontakty nauczyciela ze szkołą, już nie jako ucznia - studenta - praktykanta, ale czlowieka wykonującego swój zawód.

\section{Przygotowanie nauczyciela do zawodu}

Przygotowanie nauczyciela do zawodu miało charakter swoistej preadaptacji. Można w nim wyróżnić min.:

- decyzję o wstapieniu do seminarium nauczycielskiego, czy liceum pedagogicznego,

- przygotowanie merytoryczne i metodyczne do pracy dydaktyczno-wychowawczej,

- formację osobowościowa,

- zajecia próbne w szkole ćwiczeń,

- praktykę pedagogiczną.

W okresie międzywojennym decyzja o wyborze zawodu nauczyciela $\mathrm{i}$ wstąpieniu do seminarium nauczycielskiego, czy liceum pedagogicznego zapadala często jeszcze $w$ czasie nauki w szkole powszechnej. Wiązało się to najczęściej z sytuacją materialną rodziny, z której kandydat

1 J. Hellwig Problemy osobowości nauczyciela w polskiej myśli pedagogicznej, „ZZycie Szkoły” 1979, nr 10, 8. 3-8.

${ }^{2}$ Rozwoj pedagogiki w II Rzeczypospolitej. Problemy kontrowersyjne, red. W. Bobrowska-Nowak, Katowice 1992, s. $22-32$. 
pochodził. Skromna pozycja finansowa rodziny, możliwość stosunkowo szybkiego osiągnięcia zawodu inteligenckiego cieszącego się prestiżem społecznym, stanowiły często motyw wyboru zawodu. Ważną rolę spełniało także w znacznej części misyjne traktowanie zawodu nauczycielskiego dla poświęcenia się w pracy dla dobra innych.

W ten sposób, w zasadniczej części, do seminarium przychodziła młodzież, która raczej świadomie dokonała tego wyboru, znając w dużej mierze światła i cienie zawodu nauczycielskiego, a nawet uświadamiała sobie wielką odpowiedzialność, jaką podejmuje biorąc na siebie zadania dydaktyczne i wychowawcze związane z dziećmi. Na tej niejako podstawie latwiej było doborowej kadrze nauczycieli seminariów nauczycielskich i liceów pedagogicznych, a później także pedagogiów realizować przygotowanie merytoryczne i metodyczne oraz formowanie osobowości przyszłego nauczyciela i wychowawcy.

Niezwykle istotną rolę pogłębiając̨̨ proces formacyjny przyszłego nauczyciela spełniał internat zakładu kształcenia nauczycieli. Znaczna część uczniów seminarium i liceum pedagogicznego w nim zamieszkiwała. Miał on niejako zastępować dom rodzinny i stwarzać właściwą atmosferę dla kandydata do zawodu i kontynuować formowanie osobowości przyszłego wychowawcy. W okresie międzywojennym przyjmowano bowiem, iż zakład kształcenia nauczycieli składa się z trzech pođstawowych członów, w którym na pierwszym miejscu wymieniano internat ze względu na jego rodzinną rolę, na drugim sam zakład naukowy (liceum), a na trzecim szkolę ćwiczeń.

Szkoła ćwiczeń, ściśle złączona z zakładem kształcenia nauczycieli, była warsztatem codziennej pracy próbnej związanej nie tylko z prowadzeniem lekcji, ale także ćwiczeń natury wychowawczej w powiązaniu z procesem nauczania, jak również poprzez świetlicę szkoln̨̧, samorząd uczniowski, koła zainteresowań, drużynę harcerską, spółdzielnię uczniowską, czy też inne formy pracy pozalekcyjnej.

Ogólne przygotowanie ze szkoły ćwiczeń w konfrontacji z wiedzą zdobytą w zakładzie było dobrym przygotowaniem do praktyki pedagogicznej zapewniającej szeroki kontakt z codzienną rzeczywistością wychowawczą, umożliwiająca poszerzenie, skromnego dotąd, doświadczenia pedagogicznego. Praktyka stwarzała także podstawy do ksztaltowania postawy twórczej nauczyciela i wiazania go $z$ zawodem.

Proces kształtowania przyszłego nauczyciela stymulowany był przez nauczycieli-mistrzów, którzy znaleźli się w otoczeniu młodego kandydata. Ich oddziaływanie miało znaczenie doniosłe. Przyjmowano bowiem założenie, iż kształtowanie osobowości przyszłego nauczyciela nie może przebiegać prawidłowo bez mądrego, pełnego taktu, ale mocnego kierownictwa, słowem bez wzoru osobowego, określonego autorytetu. Bywał to jednak nie autorytet władzy, funkcji, czy stanowiska, lecz tylko osobistych walorów umysłu i charakteru.

Zjawisko to pojmowano $w$ ten sposób, iż z istoty zawodu nauczycielskiego wypływają wobec przyszłego nauczyciela wysokie wymagania dotyczace jego postawy moralnej i etyki zawodowej.

Problem ten był w centrum uwagi pedeutologów okresu międzywojennego. Wiązał się on z kwestią genezy cech osobowości. Jedni twierdzili że są one wrodzone, a inni, że nabyte we wczesnym dzieciństwie; jeszcze inni wychodzili z założenia, że są one możliwe do ukształtowania w procesie przygotowania zawodowego $\mathrm{i}$ pod wpływem pracy zawodowej.

Wymienione aspekty, najprawdopodobniej niepełne, były w okresie międzywojennym przedmiotem licznych badań naukowych i przemyślen (poza, jak się wydaje, problemem decyzji dotyczącej wstąpienia do seminarium nauczycielskiego) polskich pedeutologów i teoretyków pedagogiki.

Tematy te, podejmowane przez bogate piśmiennictwo z tego okresu, były kontynuowane w okresie powojennym przy wykorzystaniu materiału naukowego zyskanego przed wojną. Stąd też nie będziemy ich na tym miejscu szerzej rozwijali. Skupimy się natomiast nieco szerzej na wartym, w moim przekonaniu, szczegółowego poznania naukowego zasadniczym okresie adaptacyjnym, okresie zżywania się nauczyciela ze szkołą i zawodem, identyfikacją z nim. 


\section{Pierwsze kontakty mlodego nauczyciela ze szkołą}

Nauczyciel podejmując pracę dydaktyczną w szkole wchodzi w zupełnie inną, nową role społeczną ${ }^{3}$ różną od tej, jaką spetniał prowadząc lekcje próbne w szkole ćwiczeń lub odbywając praktyki zawodowe przewidziane planem nauczania, pozostając nieustannie $w$ dalszym ciągu uczniem zakładu kształcenia nauczycieli. Ta ostatnia byla rolą praktykanta, obecna zaś rolą pracownika, nauczyciela, którego funkcja społeczna traktowana była ciągle jeszcze na zasadzie tradycji jako swoista misja4.

Teorie pedeutologiczne okresu międzywojennego oraz codzienna praktyka szkolna, a w szczególności pomysły doświadczonych nauczycieli i wychowawców przyczyniły się do wypracowania pewnych form pracy $\mathrm{z}$ młodym nauczycielem. Prawdopodobnie nie były one w całości stosowane, ale analizowane komplementarnie mogły stworzyć swoisty program (ceremoniał) pracy wokół młodego nauczyciela celem jego prawidłowej adaptacji do pracy $w$ szkole $i$ identyfikacji z zawodem. Praktyka bowiem potwierdzała, a współcześnie dowodzą tego także efekty badań naukowych, że już pierwszy kontakt nauczyciela (pracownika) z przyszłym zakładem pracy (szkoła, placówką oświatowo-wychowawczą) jest niezwykle ważny. Każdemu człowiekowi w czasie podejmowania pracy towarzyszą bowiem silne przeżycia emocjonalne. Przeżycia te są znacznie intensywniejsze u początkującego pracownika (nauczyciela). Wzmożone przeżycia emocjonalne, towarzyszące zetknięciu z nową sytuacją powodują zjawiska, które można umownie nazwać „sytuacją oczekiwañ". Młody nauczyciel oczekuje czegoś (spodziewa się czegoś) i w zależności od posiadanego już doświadczenia życiowego stawia sobie szereg pytań i problemów związanych z przyszłą praca. Te pytania i problemy dotyczyć mogą najróżnorodniejszych spraw. Zależy to, jak wspomnieliśmy, od doświadczenia życiowego kandydata. Angażują one tak dalece jego osobowość, że utrudniają często i opóźniaja twórcze przystosowanie do nowych warunków. W konsekwencji zaś powodują znacznie powolniejsze wejście $w$ proces pracy dydaktyczno-wychowawczej i organizacyjnej, i osiagganie w nich właściwej efektywności. Niedostatek informacji, niechętny albo obojętny stosunek do nowego pracownika (nauczyciela) pogłębia te zjawiska.

Stąd też odpowiednie zabiegi pedagogiczne zmierzają do ułatwienia młodemu nauczycielowi adaptacji do nowych warunków i kształtowania w sposób pożądany środowiska swej pracy.

Można w nich wyróżnić m.in.:

- maksymalne uproszczenie czynności formalno-prawnych (biurokratycznych) związanych z przyjeciem nowego nauczyciela do pracy, załatwienie ich sprawnie i uprzejmie. Towarzyszyła im ewidentna troska o młodego nauczyciela $\mathrm{i}$ jego indywidualne problemy. Dażono do tego, by młody nauczyciel z pierwszych kontaktów z władza wyniósł pełne przekonanie, że jest naprawdę potrzebny i że szkoła, w której ma pracować oczekuje go;

- duże znaczenie miewała też ciepła i serdeczna rozmowa inspektora, czy kierownika szkoły $z$ młodym nauczycielem nacechowana życzliwością i troską o jego przyszłą pracę (rola kierownika szkoły w procesie adaptacji była zawsze $\mathrm{z}$ calym naciskiem podkreślana);

- duże znaczenie miało także przedstawienie młodego nauczyciela pozostałym członkom grona nauczycielskiego oraz przydzielenie mu wcześniej przygotowanego do tej roli mentora. Był to zwykle doświadczony nauczyciel, doradca, opiekun i przewodnik, który podejmował sį̨ szczególnej troski o „nowicjusza” w początkowym okresie jego pracy. Mentorem bywał nauczyciel odznaczający się odpowiednimi cechami osobistymi oraz znajomością stosunków, zwyczajów i klimatu zarówno w środowisku wewnątrzszkolnym, jak i otoczeniu zewnętrznym. Opieka obejmowała zarówno sprawy zawodowe, jak i osobiste. Czas tej opieki bywał trudny do

\footnotetext{
${ }^{3}$ B. Bromberek, Role spoleczene nauczyciela, Poznań 1973.

4. Hellwig, Problemy...; por. tegoż, Wklad Zwiqzku Nauczycielstwa Polskiego w ksztalcenie i doksztalcanie nauczycieli w Polsce (1919-1968), Poznań 1973.
} 
jednoznacznego ustalenia dla wszystkich początkujących nauczycieli. Rozpatrywano go indywidualnie i przerywano w zależności od potrzeb i charakteru początkującego nauczyciela;

- niebagatelne znaczenie miało również zapoznanie młodego nauczyciela bądź to przez kierownika szkoły, bądź przez wyznaczonego mentora z warunkami pracy szkoły, w szczególności zaś z charakterystyką społeczności lokalnej, a także warunkami pracy szkoły, zasobami dydaktycznymi, wyposażeniem w środki dydaktyczne itp.;

- dalszym etapem wspomnianego ceremoniału wprowadzenia młodego nauczyciela do pracy bywała wnikliwa, ale nacechowana życzliwością i chęcią niesienia pomocy, obserwacja młodego wychowawcy, podyktowana nie napastliwą inwigilacją, ale troską o dokladniejsze poznanie go, o jego dobro $i$ udzielenie mu sukcesywnych porad w procesie adaptacji $i$ identyfikacji z zawodem. Ten proces obejmował instruktywne hospitacje, kontrolę konspektów, lekcje koleżeńskie, udział w posiedzeniach rad pedagogicznych, w konferencjach rejonowych i metodycznychs, wskazanie na możliwości korzystania z biblioteki szkolnej i innych zasobów źródeł wiedzy, przygotowanie i odbycie tzw. egzaminów nauczycielskich, w okresie gdy one obowiazywały. Proces ten zawierał ważna przesłankę uświadamiająç młodemu nauczycielowi fakt konieczności stałego doskonalenia się, gdyż specyficzna sytuacja szkolna i mogąca zapanować w niej rutyna może prowadzić do stagnacji, a w konsekwencji do różnych dewiacji w tak szczególnym zawodzie, jakim jest zawód nauczycielski.

Wydaje się, że współczesna praktyka związana $\mathrm{z}$ adaptacj̨̨ młodego nauczyciela do pracy i identyfikacji z zawodem, wsparta o osiagnięcia współczesnej nauki, w szczególności pedagogiki i psychologii oraz socjologii pracy, moglaby $z$ powodzeniem $z$ fragmentarycznie wymienionych w tym artykule i wyrywkowo stosowanych w okresie międzywojennym form stworzyc zwarty, przemyślany i naukowo zweryfikowany program pracy adaptacyjnej $\mathrm{z}$ młodym nauczycielem.

Pierwsze lata pracy w szkole maja bowiem istotny wpływ na dalszą karierę zawodową nauczyciela.

S J. Hellwig, Konferencje rejonowe jako formy ksztalcenia permanetnego nauczycieli, „Neodidagmata” 1975, T. VI, s. $137-154$. 